$$
\begin{gathered}
\text { 행복결정요인이 지 역주민 건강인식에 미치는 영향 연구 } \\
\text { 남희은 }{ }^{1}, \text { 백정원 }^{2}, \text { 류지선 }^{3} \\
{ }^{1} \text { 고신대학교 사회복지학과, }{ }^{2} \text { 동부산대학 보건의료행정과, }{ }^{3}{ }^{1} \text { 산대학교 사회복지학과 }
\end{gathered}
$$

\title{
Study on Effect about The Determinants of Happiness to The Local Residents of Their Cognition of Health
}

\author{
Hee-Eun Nam ${ }^{1 \neq}$, Jeong-Won Baek², Ji-Sun $\mathrm{Ryu}^{3}$ \\ ${ }^{1}$ Dept. of Social Welfare, Kosin University, \\ ${ }^{2}$ Dept. of Health Administration, Dong-Pusan College University, \\ ${ }^{3}$ Dept. of Social Welfare, Busan National University
}

\begin{abstract}
$<$ Abstract $>$
This study focused on 'The Health' which should considered as a precondition for the local residents by reinvestigating the indicators of happiness after Young-Do ward formulate a community social welfare plan. There is purpose of this study as below. I searched an general attribute and the indicators of happiness, then looked how does results from questions about health and factors of the indicators of happiness can affects the health with some kinds of elements.

Five hundred people from the inhabitants of Young-Do ward who is living in Young-Do district were separated by using the random sampling method as the subject of the study. The investigation took effect from October to November of 2010 and an investigator visited the inhabitants of a ward with structured questionnaire. An investigator had one-on-one talk with inhabitants of Young-Do ward while the investigation and I also collected the data through self-administered questionnaire as well.

I found the physical elements influence in the health much more than the outside factors from the study. Higher satisfaction of their career, relationship between friends and co-workers, work environment and married life reflects the fact that higher self-contentment means high quality health level.
\end{abstract}

Key Words : Determinants of Happiness, Cognition of Health, Indicators of Happiness 


\section{I . 서론}

\section{1. 연구의 필요성 및 목적}

'어떻게 사는 것이 행복한 삶인가?' 라는 가장 기본적인 질문은 누구나 한번쯤은 스스로에게 던 져보는 근본적인 물음일 것이다. 경제적인 풍요, 주거의 안정, 건강, 가족 등 수많은 요인들이 행복 이라는 답을 찾기 위해 그려지는 변수이다. 최근 인간의 행복에 대한 관심이 전 세계적으로 고조되 면서 행복의 개념, 행복의 결정요인, 행복수준, 삶 의 질, 웰빙 이라는 개념에 대해 다양한 연구가 진 행되고 있다. 이러한 흐름과 더불어 미국 미시간대 사회연구소는 1981년부터 매년 전 국가를 대상으 로 국내총생산(GDP), 인간개발지수(HDI)를 통해 행복지수를 조사-발표하고 있다. 결과를 보면 경 제개발과 국민들의 행복감은 반드시 비례하지 않 음을 알 수 있다. 이는 행복, 삶의 질이라는 개념 은 절대적인 기준에서 보는 것이 아닌 시대, 사회, 문화적인 것과 맞물린 상대적인 개념에서 나타나 는 것이기 때문이다.

이에 2008년 한국보건사회연구원에서는 한국인 의 행복에 영향을 미치는 구성요소를 문헌연구, 델 파이 조사 등을 통하여 한국인의 행복 결정요인을 살펴보았고 총 21 가지의 지표를 개발하였다[1]. 개 발된 총 21 가지의 지표를 살펴보면 행복지수의 원 래 명칭인 주관적 웰빙 순서라는 명칭에서 보듯이 각각의 지표는 독립적이기보다는 상호연관된 유기 체라는 점을 알 수 있다. 즉, 심리요인 하나만이 행복에 영향을 주는 것이 아니고 심리요인과 건강 그 외의 요인들이 유기적으로 맞물러 행복이란 주 관적인 개념을 가지는 것이라는 점을 알 수 있다.

본 연구에서는 그 중에서도 최근 웰빙, 삶의 질 이라는 키워드와 더불어 건강에 중점을 두고자 한 다. '만수무강', '건강과 젊음은 그 두 가지를 잃고
난 뒤에야 그 고마움을 안다.', '건강을 잃으면 천 하를 잃는다'와 같은 우리나라의 속담에서도 알 수 있듯이 행복감이라는 것은 단순하게 경제적인 풍 족 만이 최고가 아니라는 것을 나타내고 있다. 2010년 부산광역시 영도구 지역복지계획의 결과를 살펴보면 부산광역시 영도구 지역주민의 행복지수 는 한국인의 평균 점수에 비해 전반적으로 낮음을 알 수 있었다[2]. 이에 본 연구에서는 부산광역시 영도구 지역사회복지계획의 경우에서 나타난 결과 가 사회복지수급대상자의 수가 많아서 행복지수가 낮은 것인지? 아니면 부산광역시 영도구 지역만의 특성인지를 알아보기 위해 재조사에 이르게 되었 다. 더불어 사람들에게 있어 가장 기본적인 전제요 건인 '건강' 이라는 것에 초점을 맞추어 행복결정 요인 중 건강요인에 중점을 두고 다음과 같은 연 구목적을 가진다.

첫째, 조사지역 주민들의 일반적인 특성을 살펴 보고 그들의 행복지수를 알아본다.

둘째, 지역주민들의 건강에 대한 각각의 문항에 대한 행복지수의 분포를 알아본다.

셋째, 행복지수의 요인들이 건강에 영향을 준다 면 얼마나 영향을 미치는지 살펴봄으로서 건강을 인식하는 데에는 어떠한 요소들이 있는지 알아본 다.

2. 선행연구

1) 행복결정요인과 행복지수

행복에 대한 연구는 몇몇 학자에 의해 개발되어 져 왔다. 뉴가르텐-해비거스트 및 토빈 (Neugarten, Havighurstand Tobin, 1961)이 개발한 삶의 만족도 척도는 삶의 만족도 연구에서 보건과 질병 측면을 강조하고 있는 대표적인 연구지만 사 회노년학 분야에서 개발되어 시민전체를 대상으로 연구하기에는 한계가 있다. 김신영 - 백혜정(2008) 
은 청소년행복지수개발을 위해 선행연구들을 검토 한 후 미국에서 개발한 '청소년행복지수(Child Well-Being Index)'의 기준을 적용하였다[3]. 김명 소·한영석(2006)은 한국인이 생각하는 행복의 주 관적 · 객관적 구성요소를 파악하고, 이를 바탕으로 Focus Group Interview(전문가심층면접조사 : 이하 $\mathrm{FGI}$ 와 설문조사를 실시하여 16 개의 행복요인을 도출 하였고, 이들 요인을 알더퍼(Alderfer)의 ERG 이론에 따라 3 요소로 재분류한 뒤 구조방정식을 이용하여 한국인의 행복지수 공식을 개발하였다 [4]. 또한 2008년 보건사회연구원에서는 한국인의 행복결정요인은 무엇이며, 행복지수가 어떠한가를 파악하여 정책결정에 주요한 지표로 반영하는 척 도가 요구됨에 따라 한국인의 행복에 영향을 미치 는 구성요소를 파악하였다. 우선 행복결정요인을 1,2 차에 걸쳐 개발 - 분석하였고 행복지수를 측정함 으로써 보다 행복해지기 위한 개인적 및 정책적 방안을 제시하였다[1].

2) 건강과 다른 요인과의 관계에 관한 선행연구

건강과 다른 요인과의 관계에 대해서는 많은 연 구가 진행되어져 왔다. 지역사회와 건강과의 요인 에 있어 정민수, 조병희(2006)의 연구에서는 최근 보건학에서 지역사회역량 개념을 적용하여 연구한 사례들은 대체로 지역사회를 단위로 한 사회심리 학적 요인의 건강효과를 보거나 건강증진 프로그 램의 효과적인 작동에 관심을 가졌고 건강은 사회 적인 것이기에 개인적인 노력과 함께 집합적 노력 의 필요성을 강조하고 있다[5]. 최말옥(2010)의 부 산시민의 남성과 여성의 행복감에 영향을 주는 요 인을 비교한 연구에서는 낙관주의적 사고는 행복 감을 증진하고 교육정도나 월소득의 경우 영향을 주기는 하지만 상대적으로 많은 영향을 미치지는 않는다는 결론이 나왔다[6]. 또한 사회관계적 요소 의 경우 사회적 지지가 삶의 질에 큰 영향을 미치
며 박길성(2002)의 연구에서는 한국사회에서는 공 식적 단체가입 등과 같은 사회적 관계망 가입은 삶의 질에 영향을 미침을 보여주고 있다[7].

\section{ㅍ. 연구방법}

1. 조사 대상

본 연구에서는 통계적 분석을 위해 부산시 부산 광역시 영도구청이 주관한 『구민만족도 및 행복 지수조사 결과 만족도』자료를 활용하였다. 조사대 상은 부산광역시 영도구 내 거주 하는 만13세 이 상의 구민을 대상으로 임의추출방법을 통해 부산 광역시 영도구민 500명을 추출하였다. 조사는 2010 년 10 월 11 월에 걸쳐 실시되었으며 면접조사원이 구민을 방문하여 구조화된 설문지를 활용하여 일 대일 면접조사 및 자기기입식의 설문을 통해 수집 되었다.

\section{2. 측정도구}

본 연구에서는 2008년 한국보건사회연구원에서 행복 관련 이론에 대한 선행연구를 기존 국내·외 기존 문헌을 통해 검토 후 행복지표를 개발하고 지표의 우선순위를 설정하기 위해 전문가와 일반 인을 대상으로 델파이조사를 실시하여 결정한 한 국인의 행복결정요인 지표를 사용하였다[1]. 지표 는 총 21개 문항으로 구성되어있으나 본 연구에서 는 수정하여 심리적 안정 2문항, 가족-결혼 관련 2 문항, 개인적 관계 2 문항, 지역사회 1 문항, 일상생 활 1 문항, 경제적 안정 2 문항, 일과관련 3 문항, 건 강관련 3 문항, 주거관련 1 문항으로 총 17 문항으로 구성되어 있다. 각 문항은 0 점부터 10 점까지의 자 가 척도로 구성되어 있다. 
3. 자료분석방법

설문의 일반적인 특성 및 행복지수의 평균을 알 아보기 위해서는 SPSS 18.0 을 이용하여 기술통계 를 사용하였으며 건강수준요인에 영향을 미치는 행복결정요인의 영향을 분석하기 위해서 다중회귀 분석을 이용하였다.

\section{III. 연구결과}

1. 연구대상의 일반적 사항

<표 1> 응답자의 일반적 특성

\begin{tabular}{|c|c|c|c|}
\hline & 구분 & 빈도 & 퍼센트 \\
\hline \multirow{3}{*}{ 성별 } & 남자 & 122 & 24.6 \\
\hline & 여자 & 373 & 75.4 \\
\hline & 합계 & 495 & 100.0 \\
\hline \multirow{8}{*}{ 연령 } & 10대 & 6 & 1.2 \\
\hline & 20대 & 95 & 19.3 \\
\hline & 30대 & 101 & 20.5 \\
\hline & 40대 & 106 & 21.5 \\
\hline & 50대 & 113 & 23.0 \\
\hline & 60대 & 50 & 10.2 \\
\hline & 70대 이상 & 21 & 4.3 \\
\hline & 합계 & 492 & 100.0 \\
\hline \multirow{4}{*}{$\begin{array}{l}\text { 결혼 } \\
\text { 여부 }\end{array}$} & 미혼 & 146 & 30.0 \\
\hline & 기혼 & 304 & 62.4 \\
\hline & 이혼/사별 & 37 & 7.6 \\
\hline & 합 계 & 487 & 100.0 \\
\hline \multirow{10}{*}{$\begin{array}{l}\text { 직업 } \\
\text { 분포 }\end{array}$} & 자영업 & 38 & 7.9 \\
\hline & 판매/서비스직 & 17 & 3.5 \\
\hline & 생산/기술직 & 18 & 3.8 \\
\hline & 일반사무직 & 90 & 18.8 \\
\hline & 관리직 & 5 & 1.0 \\
\hline & 전문직 & 51 & 10.6 \\
\hline & 주부 & 114 & 23.8 \\
\hline & 청소년 & 6 & 1.3 \\
\hline & 대학생 & 33 & 6.9 \\
\hline & 합계 & 492 & 100.0 \\
\hline
\end{tabular}

응답자의 연령대별 분포를 살펴보면 가장 많은 응답을 한 연령대는 50 대(23.0\%)이며 다 음은 40 대(21.5\%), 30대(20.5\%)의 순을 보임을 알 수 있었다. 응답자의 결혼여부를 보면 기 혼자가 304 명 $(62.4 \%)$ 로 가장 많이 차지하고 있었고, 미혼이 145 명(30.0\%)이었으며 이혼 및 사별인 응답자가 37 명 $(7.6 \%)$ 의 분포를 보 임을 알 수 있었다. 응답자의 직업분포를 보 면 주부가 114 명(23.8\%)로 가장 많은 분포를 보였으며 다음으로 일반사무직이 90명 $(18.8 \%)$, 전문직이 90명(18.8\%), 기타로 응답 한 직업군이 83 명 $(17.3 \%)$ 의 순으로 나타났다 <표 1>.

2. 행복결정요인에 관한 기술통계

17 가지의 행복결정요인에 따른 행복지수의 평균을 보면 부산시 영도지역의 경우 자신의 일에 대한 보람이 6.51점으로 가장 높게 나 왔으며 다음으로는 주거의 소유에 대한 만족 이 6.06, 원하는 것을 가질 수 있다는 유능감 이 5.57로 높았다. 2008년 보건사회연구원에 서 조사한 한국인의 평균 행복지수와 비교해 보았을 때에는 전체적으로 점수가 조금씩 낮 음을 알 수 있었다<표 2>. 
<표 2> 행복결정요인별 기술통계

\begin{tabular}{|c|c|c|c|c|c|}
\hline & 요인 & $\mathrm{N}$ & 표준편차 & 평균 & 한국인평균 \\
\hline \multirow{2}{*}{ 심리적안정 } & 자신에 대한 자아존중감 & 493 & 2.144 & 6.77 & 7.03 \\
\hline & 긍정적인 가치관 및 감정상태 & 491 & 2.187 & 6.66 & 7.13 \\
\hline \multirow{2}{*}{ 가족,결혼 } & 가족(결혼)생활에 대한 만족상태 & 482 & 2.488 & 6.80 & 7.43 \\
\hline & 부부생활(이성교제)에 대한 만족상태 & 481 & 2.605 & 6.56 & 6.94 \\
\hline \multirow{2}{*}{ 개인적관계 } & 가족원과의 관계에 대한 만족상태 & 487 & 2.412 & 7.11 & 7.98 \\
\hline & 친구 및 동료관계에 대한 만족상태 & 490 & 2.215 & 7.09 & 7.39 \\
\hline 지역사회 & 지역사회환경에 대한 만족상태 & 493 & 2.046 & 6.14 & 6.18 \\
\hline 일상생활 & 여가 및 휴식에 대한 만족상태 & 492 & 2.235 & 6.00 & 6.25 \\
\hline \multirow{2}{*}{ 경제적안정 } & 원하는 만큼 재산(소득)을 소유(취득)하고 있다는 충족감 & 492 & 2.298 & 5.39 & 6.82 \\
\hline & 원하는 것을 언제든 사거나 가질 수 있다는 유능감 & 490 & 2.335 & 5.57 & 5.46 \\
\hline \multirow{3}{*}{ 자신의 일 } & 자신의 일에 대한 보람 & 490 & 2.355 & 6.51 & 5.84 \\
\hline & 하고 있는 일의 종류와 원하는 것과의 일치 정도 & 492 & 2.354 & 6.27 & 6.70 \\
\hline & 일에 대한 급여, 근무환경에 대한 만족상태 & 490 & 2.293 & 5.68 & 6.18 \\
\hline \multirow{3}{*}{ 건강 } & 주관적인 건강수준 & 491 & 2.204 & 6.24 & 6.28 \\
\hline & 가족의 건강수준 & 492 & 2.126 & 6.52 & 6.80 \\
\hline & 규칙적인 운동 여부 & 493 & 2.534 & 5.62 & 7.38 \\
\hline 주거 & 주거의 소유 및 질에 대한 만족상태 & 492 & 2.308 & 6.06 & 5.39 \\
\hline
\end{tabular}

<표 3> 각 결정요인과 행복지수 총점과의 상관관계

\begin{tabular}{|c|c|c|c|}
\hline \multirow{2}{*}{ 요인 } & \multicolumn{3}{|c|}{ 행복지수 } \\
\hline & Pearson 상관계수 & 유의확률 & $\mathrm{N}$ \\
\hline 자신에 대한 자아존중감 & $.775(* \star)$ & .000 & 452 \\
\hline 긍정적인 가치관 및 감정상태 & $.770(* *)$ & .000 & 452 \\
\hline 가족(결혼)생활에 대한 만족상태 & $.770(* *)$ & .000 & 452 \\
\hline 부부생활(이성교제)에 대한 만족상태 & $.714(* *)$ & .000 & 452 \\
\hline 가족원과의 관계에 대한 만족상태 & $.773(* \star)$ & .000 & 452 \\
\hline 친구 및 동료관계에 대한 만족상태 & $.746(* *)$ & .000 & 452 \\
\hline 지역사회환경에 대한 만족상태 & $.723(* *)$ & .000 & 452 \\
\hline 여가 및 휴식에 대한 만족상태 & $.715(* *)$ & .000 & 452 \\
\hline 원하는 만큼 재산(소득)을 소유(취득)하고 있다는 충족감 & $.730(* *)$ & .000 & 452 \\
\hline 원하는 것을 언제든 사거나 가질 수 있다는 유능감 & $.751(* *)$ & .000 & 452 \\
\hline 자신의 일에 대한 보람 & $.826(* *)$ & .000 & 452 \\
\hline 하고 있는 일의 종류와 원하는 것과의 일치 정도 & $.783(* *)$ & .000 & 452 \\
\hline 일에 대한 급여, 근무환경에 대한 만족상태 & $.700(* *)$ & .000 & 452 \\
\hline 주관적인 건강수준 & $.769(* \star)$ & .000 & 452 \\
\hline 가족의 건강수준 & $.753(* *)$ & .000 & 452 \\
\hline 규칙적인 운동 여부 & $.617(* *)$ & .000 & 452 \\
\hline 주거의 소유 및 질에 대한 만족상태 & $.789(* *)$ & .000 & 452 \\
\hline
\end{tabular}

*** $\mathrm{p}<.001$ ** $\mathrm{p}<.01 * \mathrm{p}<.05$ 
행복지수 총점은 17 가지 행복결정요인들의 점수 를 모두 더한 후 평균값을 구하는 방식으로 측정 하였다. 그 결과 전체 행복지수는 6.34 점 $(\mathrm{N}=452$, 결측치 제외)으로 나타났다. 행복지수와 결정요인 들 간에 어떠한 상관관계가 있는지를 파악하기 위 해 상관관계 분석을 실시한 결과는 다음과 같다 <표 3>. 표에서 나타난 것처럼, 각 결정요인들은 행복지수 총점과 양의 상관관계를 가진다. 특히, 자신의 일에 대한 보람은 행복지수 총점과의 피어 슨 상관계수가 0.862 로 가장 높게 나타났다. 다음 으로 주거의 소유 및 질에 대한 만족상태가 피어 슨 상관계수 0.789 , 하고 있는 일의 종류와 원하는 것과의 일치 정도가 0.783 , 자신에 대한 자아존중 감 0.775 , 가족원과의 관계에 대한 만족상태 0.773 등이 뒤를 이었다.

17 개의 결정요인들의 피어슨 상관계수는 서로 근소한 차이가 있을 뿐, 대체로 모든 결정요인들이 행복지수 총점과 높은 상관관계를 가지는 것으로 보인다. 즉, 심리, 가족, 관계, 지역사회, 일상생활,
경제, 일, 건강, 주거 영역 모두 행복지수 총점과 비슷한 정도의 상관관계를 가졌다고 볼 수 있다.

그러므로 주관적인 건강수준, 가족의 건강수준, 규칙적인 운동 여부 등으로 구성된 건강 요인도 행복지수에 있어서 중요한 항목으로 판단할 수 있 다.

3. 건강에 대해 느끼는 주관적인 행복지수

한 개인이 행복감을 느끼는 여러 가지 결정요인 들 중 건강에 대한 결정요인의 중요성은 누구나 공감할 수밖에 없으며, 건강은 행복하기 위한 필요 조건으로 간주되는 것이 일반적이다. 건강에 대해 지역주민들의 인식을 구체적으로 살펴보면, 현재의 주관적인 건강수준은 6.24점, 가족의 건강수준에 대한 평균 점수는 6.52점, 규칙적인 운동여부는 5.62 점이며 각 점수대별 분표는 아래와 같다<그림 $1>,<$ 표 $4>$.

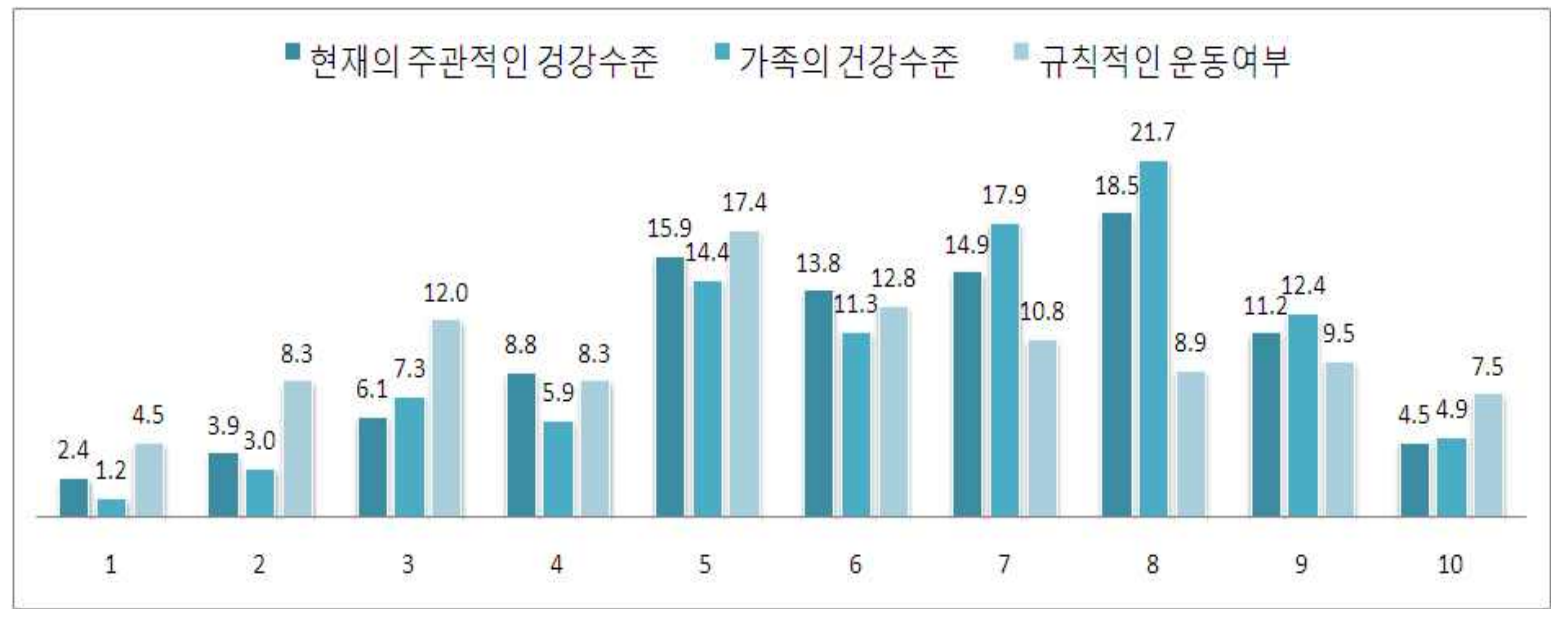

<그림 1> 건강요소별 그래프 
<표 4> 건강요소별 분포표

단위: \%

\begin{tabular}{lccccc}
\hline \multirow{2}{*}{ 지표 } & $1 \sim 2$ & $3 \sim 4$ & $5 \sim 6$ & $7 \sim 8$ & $9 \sim 10$ \\
\cline { 2 - 6 } & 매우 불만족 & 대체로 불만족 & 보통 & 대체로 만족 & 매우 만족 \\
\hline \hline 현재의 주관적인 건강수준 & 6.3 & 14.9 & 29.7 & 33.4 & 15.7 \\
가족의 건강수준 & 4.2 & 13.2 & 25.7 & 39.6 & 17.3 \\
규칙적인 운동여부 & 12.8 & 20.3 & 31.2 & 19.7 & 17.0 \\
\hline
\end{tabular}

4. 행복결정요인이 건강수준요인에 영향을 미 치는 정도

행복결정요인들은 건강이라는 요인에 어떠한 관 계를 가지고 있는지, 그리고 얼마만큼의 영향력을 가지고 있는지를 살펴보기 위해 다중회귀분석을
실시하였다. 건강에 관한 세 가지 결정요인을 건강 이라는 하나의 변수로 묶은 후 종속변수로 삼고, 나머지 14 개의 행복결정요인들을 독립변수로 동시 에 투입하여 다중회귀분석을 한 결과는 <표 5>와 같다.

<표 5> 한국인 행복결정요인과 건강 수준 요인 간의 회귀|분석 결과(N=452)

\begin{tabular}{|c|c|c|c|c|c|c|c|}
\hline \multirow{2}{*}{ 요인 } & \multicolumn{2}{|c|}{ 비표준화 계수 } & \multirow{2}{*}{$\begin{array}{l}\text { 표준화 } \\
\text { 계수 } \\
\text { 베타 }\end{array}$} & \multirow{2}{*}{$\mathrm{t}$} & \multirow{2}{*}{$\begin{array}{c}\text { 유의확 } \\
\text { 률 }\end{array}$} & \multicolumn{2}{|c|}{ 공선성 통계량 } \\
\hline & B & $\begin{array}{c}\begin{array}{c}\text { 표준오 } \\
\text { 차 }\end{array} \\
\text {. }\end{array}$ & & & & $\begin{array}{c}\text { 공차한 } \\
\text { 계 }\end{array}$ & VIF \\
\hline (상수) & 2.165 & .507 & & 4.267 & .000 & & \\
\hline 자신에 대한 자아존중감 & .240 & .105 & .113 & $2.283 *$ & .023 & .330 & 3.032 \\
\hline 긍정적인 가치관 및 감정상태 & .077 & .105 & .037 & .733 & .464 & .312 & 3.204 \\
\hline 가족(결혼)생활에 대한 만족상태 & -.087 & .096 & -.049 & -.913 & .362 & .282 & 3.545 \\
\hline 부부생활(이성교제)에 대한 만족상태 & .148 & .081 & .087 & 1.832 & .068 & .364 & 2.749 \\
\hline 가족원과의 관계에 대한 만족상태 & .102 & .100 & .055 & 1.020 & .308 & .280 & 3.574 \\
\hline 친구 및 동료관계에 대한 만족상태 & .241 & .098 & .118 & $2.460 *$ & .014 & .356 & 2.813 \\
\hline 지역사회환경에 대한 만족상태 & -.182 & .101 & -.083 & -1.807 & .071 & .388 & 2.577 \\
\hline 여가 및 휴식에 대한 만족상태 & .186 & .088 & .093 & 2.123 & .034 & .419 & 2.384 \\
\hline 원하는만큼 재산(소득)을소유(취득)하고 있다는 충족 & -.059 & .093 & -.030 & -.634 & .526 & .362 & 2.761 \\
\hline 원하는 것을 언제든 사거나 가질 수 있다는유능감 & .101 & .090 & .052 & 1.126 & .261 & .376 & 2.663 \\
\hline 자신의 일에 대한 보람 & .416 & .102 & .219 & 4.068 & .000 & .281 & 3.565 \\
\hline 하고 있는 일의 종류와 원하는 것과의 일치정도 & .146 & .099 & .076 & 1.480 & .140 & .305 & 3.278 \\
\hline 일에 대한 급여, 근무환경에 대한 만족상태 & .146 & .086 & .075 & 1.691 & .092 & .416 & 2.404 \\
\hline 주거의 소유 및 질에 대한 만족상태 & .472 & .088 & .242 & 5.390 & .000 & .402 & 2.487 \\
\hline
\end{tabular}


첫째, 자신에 대한 자아존중감은 회귀계수가 $.240(\mathrm{p}<.05)$ 으로 통계적으로 유의미하게 건강 수준 요인에 정적인 영향을 미치는 것으로 나타났다. 자 아존중감이 건강관리 행위, 건강 인식 수준 등에 영향을 끼친다는 연구는 다양한 인구집단을 대상 으로 이루어져 왔다. 예를 들어, 이익섭 등(2007)은 의료급여 수급자의 자아존중감 정도가 건강관리행 위에 통계적으로 유의미한 영향을 미치고, 건강관 리행위 또한 이들이 지각하는 삶의 질에 통계적으
로 유의미한 영향을 주고 있음을 주장했다. 또한 자아존중감이 삶의 질에 유의미한 영향을 미치는 것으로 나타나 결국 건강관리행동은 부분매개효과 를 지니는 것으로 검증되었다[8].

둘째, 친구 및 동료관계에 대한 만족상태 회귀 계수 .241( $\mathrm{p}<.05)$ 로 통계적으로 유의미하게 나타났 다. 즉, 친구 및 동료관계에 대한 만족도가 높을수 록 건강인식이 좋은 것으로 해석할 수 있다.

<표 6> 한국인 행복결정요인과 건강 수준 요인 간의 단계적 회귀분석 결과 $(\mathrm{N}=452)$

\begin{tabular}{|c|c|c|c|c|c|c|c|c|}
\hline \multirow{2}{*}{ 모형 } & & \multicolumn{2}{|c|}{ 비표준화 계수 } & \multirow{2}{*}{$\begin{array}{c}\text { 표준화 } \\
\text { 계수 } \\
\text { 베타 }\end{array}$} & \multirow[t]{2}{*}{$\mathrm{t}$} & \multirow[t]{2}{*}{$\begin{array}{l}\text { 유의 } \\
\text { 확률 }\end{array}$} & \multicolumn{2}{|c|}{ 공선성 통계량 } \\
\hline & & B & $\begin{array}{l}\text { 표준 } \\
\text { 오차 }\end{array}$ & & & & $\begin{array}{l}\text { 공차 } \\
\text { 한계 }\end{array}$ & VIF \\
\hline \multirow{2}{*}{1} & (상수) & 6.033 & .440 & & 13.714 & .000 & & \\
\hline & 자신의 일에 대한 보람 & 1.340 & .063 & .706 & 21.128 & .000 & 1.000 & 1.000 \\
\hline \multirow{3}{*}{2} & (상수) & 4.533 & .431 & & 10.513 & .000 & & \\
\hline & 자신의 일에 대한 보람 & .869 & .076 & .458 & 11.429 & .000 & .579 & 1.726 \\
\hline & 주거의 소유 및 질에 대한 만족상태 & .744 & .078 & .382 & 9.542 & .000 & .579 & 1.726 \\
\hline \multirow{4}{*}{3} & (상수) & 3.158 & .474 & & 6.664 & .000 & & \\
\hline & 자신의 일에 대한 보람 & .698 & .079 & .368 & 8.887 & .000 & .504 & 1.986 \\
\hline & 주거의 소유 및 질에 대한 만족상태 & .615 & .078 & .316 & 7.870 & .000 & .535 & 1.867 \\
\hline & 자신에 대한 자아존중감 & .481 & .080 & .227 & 6.019 & .000 & .606 & 1.650 \\
\hline \multirow{5}{*}{4} & (상수) & 2.524 & .496 & & 5.086 & .000 & & \\
\hline & 자신의 일에 대한 보람 & .608 & .081 & .320 & 7.506 & .000 & .460 & 2.175 \\
\hline & 주거의 소유 및 질에 대한 만족상태 & .585 & .077 & .301 & 7.565 & .000 & .530 & 1.887 \\
\hline & 자신에 대한 자아존중감 & .367 & .084 & .173 & 4.343 & .000 & .528 & 1.895 \\
\hline & 친구 및 동료관계에 대한 만족상태 & .306 & .081 & .149 & 3.774 & .000 & .538 & 1.858 \\
\hline \multirow{6}{*}{5} & (상수) & 2.295 & .501 & & 4.579 & .000 & & \\
\hline & 자신의 일에 대한 보람 & .532 & .086 & .280 & 6.207 & .000 & .406 & 2.466 \\
\hline & 주거의 소유 및 질에 대한 만족상태 & .529 & .080 & .272 & 6.621 & .000 & .491 & 2.038 \\
\hline & 자신에 대한 자아존중감 & .340 & .085 & .160 & 4.025 & .000 & .520 & 1.923 \\
\hline & 친구 및 동료관계에 대한 만족상태 & .328 & .081 & .160 & 4.050 & .000 & .532 & 1.880 \\
\hline & 일에 대한 급여, 근무환경에 대한 만족상태 & .192 & .075 & .098 & 2.580 & .010 & .568 & 1.762 \\
\hline \multirow{7}{*}{6} & (상수) & 2.200 & .501 & & 4.394 & .000 & & \\
\hline & 자신의 일에 대한 보람 & .505 & .086 & .266 & 5.867 & .000 & .398 & 2.513 \\
\hline & 주거의 소유 및 질에 대한 만족상태 & .524 & .080 & .269 & 6.584 & .000 & .490 & 2.040 \\
\hline & 자신에 대한 자아존중감 & .298 & .086 & .141 & 3.463 & .001 & .496 & 2.017 \\
\hline & 친구 및 동료관계에 대한 만족상태 & .295 & .082 & .144 & 3.602 & .000 & .515 & 1.941 \\
\hline & 일에 대한 급여, 근무환경에 대한 만족상태 & .174 & .075 & .089 & 2.331 & .020 & .561 & 1.783 \\
\hline & 부부생활(이성교제)에 대한 만족상태 & .140 & .062 & .082 & 2.256 & .025 & .622 & 1.607 \\
\hline
\end{tabular}


셋째, 여가 및 휴식에 대한 만족상태의 회귀계 수는 .186(p<.05)으로 다른 항목에 비해서는 다소 낮지만 정적인 영향을 미치는 것으로 나타났다.

넷째, 자신의 일에 대한 보람은 회귀계수가 $.416(\mathrm{p}<.001)$ 로 통계적으로 유의미한 항목 중 두 번째로 높게 나타났다. 일에 대한 보람이 크면 클 수록 건강에 대한 인식도 좋다는 해석이 가능하며, 건강 인식에 있어 일에 대한 보람의 중요성을 알 수 있다.

다섯째, 주거의 소유 및 질에 대한 만족상태의 회귀계수는 .472( $\mathrm{p}<.001)$ 로 가장 크게 나타났다. 실 제로 주거환경과 건강과의 관계에 대해 연구한 많 은 논문들처럼, 주거의 소유와 질에 대한 만족상태 는 건강 인식에 결정적인 영향을 미친다고 볼 수 있다. 또한, 지역주민의 건강 인식 개선을 위해서 지역사회가 어떤 일에 집중해야 하는지를 제시한 다고 볼 수 있다.

이상 모든 독립변수를 투입하는 회귀분석 결과 에 이어, 단계적 회귀분석을 실시하였다. 단계적 회귀분석은 통계적 유의도가 낮은 독립변수를 제 외하고 중회귀식을 얻는 방식이다. 즉, 통계적 유
의도가 가장 높은 변수부터 단계적으로 투입하다 가 회귀계수의 유의수준이 0.05 이하가 되면 탈락 시키는 방식이다[9]<표 5>.

분석 결과, 투입된 모든 독립변인들 중에서 6 개 변인이 건강 수준 요인을 의미 있게 설명하였다. 가장 높은 영향력을 가진 변인은 주거의 소유 및 질에 대한 만족상태로 베타 값은 0.269 로 나타났 다. 다음으로는 자신의 일에 대한 보람(베타 값 $=0.266$, 친구 및 동료관계에 대한 만족상태(베타 값 $=0.144$ ), 자신에 대한 자아존중감 (베타 값 $=0.141)$, 일에 대한 급여, 근무환경에 대한 만족상 태(베타 값 $=0.089)$ 부부생활(이성교제)에 대한 만족 상태(베타 값=0.082) 순으로 나타났다<표 6>.

즉, 자신의 일에 대한 보람이 클수록, 친구 및 동료관계에 대한 만족상태가 클수록, 자신에 대한 자아존중감이 클수록, 일에 대한 급여, 근무환경에 대한 만족상태가 클수록, 부부생활(이성교제)에 대 한 만족상태가 클수록 건강 수준이 높다고 할 수 있다. 이상의 6 개 변인은 다음 <표 7>의 모형 6 에 나타난 것처럼 건강 수준 요인의 $63.5 \%$ 를 의미 있 게 설명하였다<표 7>.

<표 7> 단계별 중회귀계수의 결정계수

\begin{tabular}{|c|c|c|c|c|c|c|c|c|c|}
\hline \multirow[b]{2}{*}{ 모형 } & \multirow[b]{2}{*}{$\mathrm{R}$} & \multirow{2}{*}{$\begin{array}{c}\mathrm{R} \\
\text { 제곱 }\end{array}$} & \multirow{2}{*}{$\begin{array}{l}\text { 수정된 } \\
\text { R 제곱 }\end{array}$} & \multicolumn{5}{|c|}{ 통계량 변화량 } & \multirow{2}{*}{$\begin{array}{l}\text { Durbin- } \\
\text { Watson }\end{array}$} \\
\hline & & & & $\begin{array}{l}\mathrm{R} \text { 제곱 } \\
\text { 변화량 }\end{array}$ & F 변화량 & 자유도1 & 자유도2 & $\begin{array}{l}\text { 유의확률 F } \\
\text { 변화량 }\end{array}$ & \\
\hline 1 & $.706(a)$ & .498 & .497 & .498 & 446.405 & 1 & 450 & .000 & \\
\hline 2 & $.763(b)$ & .583 & .581 & .085 & 91.052 & 1 & 449 & .000 & \\
\hline 3 & $.783(c)$ & .614 & .611 & .031 & 36.232 & 1 & 448 & .000 & \\
\hline 4 & $.791(d)$ & .626 & .622 & .012 & 14.241 & 1 & 447 & .000 & \\
\hline 5 & $.795(e)$ & .631 & .627 & .006 & 6.656 & 1 & 446 & .010 & \\
\hline 6 & $.797(f)$ & .635 & .631 & .004 & 5.090 & 1 & 445 & .025 & 2.001 \\
\hline
\end{tabular}




\section{IV. 결론 및 제언}

본 연구의 결과를 통해 건강에 영향을 미치는 요인은 외부적인 요인보다는 심리적인 요인이 더 많은 작용을 하는 것을 알 수 있었다. 즉, 자신의 일에 대한 보람이 클수록, 친구 및 동료관계에 대 한 만족상태가 클수록, 자신에 대한 자아존중감이 클수록, 일에 대한 급여에 대해 만족감이 클수록, 근무환경에 대한 만족상태가 클수록, 부부생활(이 성교제)에 대한 만족상태가 클수록 지역주민들이 인식하는 본인의 건강 수준이 높다는 것을 알 수 있었다. 현재 노년인구가 증가하면서 건강, 보건에 대해 관심이 증대하고 있고 이들 대상자에 대해 국가 및 지역복지의 차원에서 운동이라는 물리적 인 환경에 초점을 두고 있는 것은 사실이다. 하지 만, 실제로 연구결과에서 나타나듯이 스스로의 건 강을 인식하는 건강수준이라는 것은 물리적인 조 건보다는 내면적·심리적인 요인이 더 큰 영향을 줌을 알 수 있었다.

이에 연구결과를 바탕으로 다음과 같은 제언을 하고자 한다.

첫째, 지역복지차원에서 지역주민의 건강에 대 한 프로그램을 운영·개발 시 내면적인 그리고 심 리적인 요인을 고려한 프로그램이 적용되었으면 한다. 많은 건강에 대한 프로그램은 지역사회의 보 건소와 지역복지관을 연계한 운동처방 및 관리의 차원에서 많이 이루어지고 있다. 하지만, 앞으로 기존의 프로그램과 병행하여 심리 치료, 나들이, 자아존중감 증가 등과 같은 심리적인 부분도 함께 한다면 효과성이 증대될 것이라 예상한다.

둘째, 2010년 부산광역시 영도구 지역사회 복지 계획 보고서에서 보면 지역주민들의 행복을 위한 가장 시급한 요소로서는 여가, 문화체육시설에 대 한 욕구가 가장 컸으며 다음으로는 사회복지제도 및 시설확충에 관한 것, 교육환경개선, 보건서비스 의 개선의 순으로 나타났다<표 8>.
<표 8> 지역주민들의 행복을 위한 가장 시급한 요소

\begin{tabular}{lrr}
\hline \multicolumn{1}{c}{ 요소 } & 빈도 & 퍼센트 \\
\hline \hline 여가, 문화체육시설 확충 & 106 & 22.2 \\
사회복지 제도/시설 확충 & 104 & 21.8 \\
교육환경 개선 & 91 & 19.0 \\
보건서비스 개선 & 26 & 5.4 \\
주민센터 기능 개선 & 16 & 3.3 \\
주차/주거 공간 확보 & 57 & 11.9 \\
공원 등 자연녹지공간 확충 & 47 & 9.8 \\
청소 등 자연환경오염방지 & 26 & 5.4 \\
기타 & 5 & 1.0 \\
\hline 합계 & 478 & 100.0 \\
\hline
\end{tabular}

이러한 측면에서 살펴보면 지역주민의 행복 감을 증진하기 위해서는 건강인식이라는 측면에 서 여가, 문화를 즐길 수 있는 신체적인 측면에 서의 체육시설을 확충시키는 것은 물론 보건서 비스를 개선함으로써 행복지수를 높이는 데 도 모할 수 있으리라 생각된다.

<표 9> 공중보건시설에 대한 지역주민의 만족도

\begin{tabular}{lrrr}
\hline & 빈도 & 퍼센트 & 평균 \\
\hline \hline 매우만족 & 42 & 8.5 & \\
대체로만족 & 161 & 32.4 & \\
보통 & 195 & 39.2 & \\
대체로불만 & 63 & 12.7 & 2.74 \\
매우불만 & 28 & 5.6 & \\
\hline 합계 & 489 & 98.4 & \\
\hline
\end{tabular}

마지막으로 앞서 언급한 공중보건 시설을 확 충시키는 것에만 치중할 것이 아니라 공중보건 시설에 대한 만족도도 증가 시켜야 함을 알 수 있다. 2010년 부산광역시 영도구 지역사회복지 계획 보고서의 결과를 살펴보면 부산광역시 영 
도구의 공중보건시설에 대한 지역주민의 만족도 는 5점 척도에서 2.74점으로 그렇게 높지 않을 결과를 알 수 있었다<표 9>.

이와 같은 제언을 바탕으로 지역주민의 행복 감을 증진시키기 위해 시설 및 하드웨어적인 부 분은 물론 심리적이고 서비스의 질과 같은 소프 트웨어적인 측면에서도 다양한 개선이 앞으로 필요하고 이러한 부분에 있어서의 포괄적인 연 구가 요구된다고 할 수 있겠다.

\section{참고문헌}

1. 김승권 등(2008), 한국인의 행복결정요인과 행복지 수에 관한 연구, 한국보건사회연구원, pp.30-38.

2. 부산광역시 영도구(2010), 영도구 지역사회복지계 획보고서, 부산광역시 영도구, pp.179-181.

3. 김신영·백혜정(2008), 한국청소년행복지수 개발연 구, 한국사회학회지, Vol.42(6);:151-152.

4. 김명소·한영석(2006), 한국인의 행복수준 공식개발, 조사연구, Vol.7(2);1-38.

5. 정민수·조병희(2007), 지역사회역량이 주민 건강 수준에 미치는 영향, 보건과 사회과학, Vol.22;.153 -182 .

6. 최말옥(2010), 남성과 여성의 행복감에 영향을 주 는 요인비교, 사회과학연구, $\operatorname{Vol} .27(2) ; 35-36$.

7. 박길성(2002), 사회적 자본과 삶의 질, 아세아 연 구, Vol.108;120-137.

8. 이익섭 등(2007), 만성질환 의료급여 수급자의 자 아존중감과 삶의 질 관계와 건강관리행위의 매개 효과 검증, 사회복지정책, Vol.31;.253-255.

접수일자 2011년 8월 22일

심사일자 2011년 9월 15일

게재확정일자 2011년 10월 8일 